\title{
The Development Trend of Accounting Service Outsourcing in the Era of Big Data*
}

\author{
Lan Cui \\ Department of Accounting \\ Harbin Finance University \\ Harbin, China 150030
}

\author{
Donghui Liu \\ Department of Accounting \\ Harbin Finance University \\ Harbin, China 150030
}

\begin{abstract}
In recent years, service outsourcing has developed rapidly, and as an important role in service outsourcing, accounting service outsourcing has become a hotspot of domestic and foreign research. This paper made an analysis on the development status of accounting service outsourcing industry in the era of big data, based on which, it expounded the problems in the development of accounting service outsourcing and proposed measures to further develop accounting service outsourcing.
\end{abstract}

Keywords-big data; accounting service outsourcing; development trend

\section{INTRODUCTION}

With the development of Internet and information industry, big data has penetrated into various industries and business functions, more and more governments and enterprises are beginning to realize the importance of data to organizations. Accounting service outsourcing is no exception, and if it seizes the opportunity, uses big data, cloud computing and other technologies to optimize business structure, refine process, and transform industrial functions, new developments of accounting service outsourcing is sure to come.

For modern enterprises, accounting service outsourcing is a suitable management method in production management, and in the 1970s, accounting service outsourcing began to enter into enterprise management, and has been applied due to its unique advantages. With the advent of the era of big data, the social division of labor is becoming more and more detailed, and accounting service outsourcing should also be developed. Using data such as big data and cloud computing to strengthen data management and analysis, provide management basis and opinions for enterprises, and help enterprises make clear the market structure and situation and make them constantly adapt to the external economic environment and the choice of division of labor, which not only greatly reduces the operating costs of enterprises, optimizes resources, but also ensures that enterprises can devote more energy to the cultivation of core competitiveness, and plays an important role in strengthening enterprise management and accelerating enterprise development.

\footnotetext{
*Fund Project: This paper is the phased research result of Heilongiiang Provincial Philosophy and Social Science Research Planning Project "Research on the Promotion and Application of Accounting Service Outsourcing in Heilongjiang Province" (Project No. 14B068), with the subject host Donghui Liu.
}

When labor costs increase and the division of labor becomes more detailed, many developed countries have begun to transfer accounting services to developing countries. For example, the United States has outsourced its accounting services to India, which can greatly improve the employment rate in India. As a developing country, China has a number of accountants, with a relatively low salary paid, but very few enterprises can provide outsource accounting services for transnational corporations as no such a market is developed in China, and even the companies that provide such services are limited to foreign-funded Chinese representative offices. If China wants to get a cake in the international market of accounting service outsourcing, it must have its own unique competitive advantage; it should not only depend on cheap human resources, but should develop business operations and quality services. The wide application and rapid development of big data in China provides opportunities for this industry. China develops this business late, but it has got a certain scale, China's accounting standards have achieved international integration, its colleges and universities have also trained a large number of outstanding talents every year, coupled with the use of big data, cloud computing and other technologies, its contact with other countries around the world is strengthened, the data analysis is made based on the world environment and the scope of accounting services is expanded, etc., which lay a solid foundation for the future development of accounting service outsourcing in China.

At present, the rapid development of big data technology will inevitably play a big role in promoting the accounting service outsourcing, effectively enriching its form, expanding its development market, and promoting the effective transformation of the industry. Based on big data, accounting service outsourcing also achieves cost-effective and more professional development, so the accounting service outsourcing under big data will inevitably receive more attention, and with the attention increasing, the demands of the service receivers are also more diversified. For these, it is necessary to explore the problems and provide solutions.

\section{THE ANALYSIS OF THE DEVELOPMENT OF ACCOUNTING} SERVICE OUTSOURCING INDUSTRY IN THE ERA OF BIG DATA

The so-called outsourcing refers to when the human resources are limited but in order to obtain the highest profit at the lowest cost, the enterprise hand over the non-core business 
to the service agency, while the accounting service outsourcing is one of the outsourcing. The emergence of big data has brought the climax of the development of new industries in the construction of computational models, the effective allocation of resources, and the innovation of information technology. In the field of service outsourcing, big data has enriched its form, broadened its development market, and promoted its industrial upgrading and transformation.

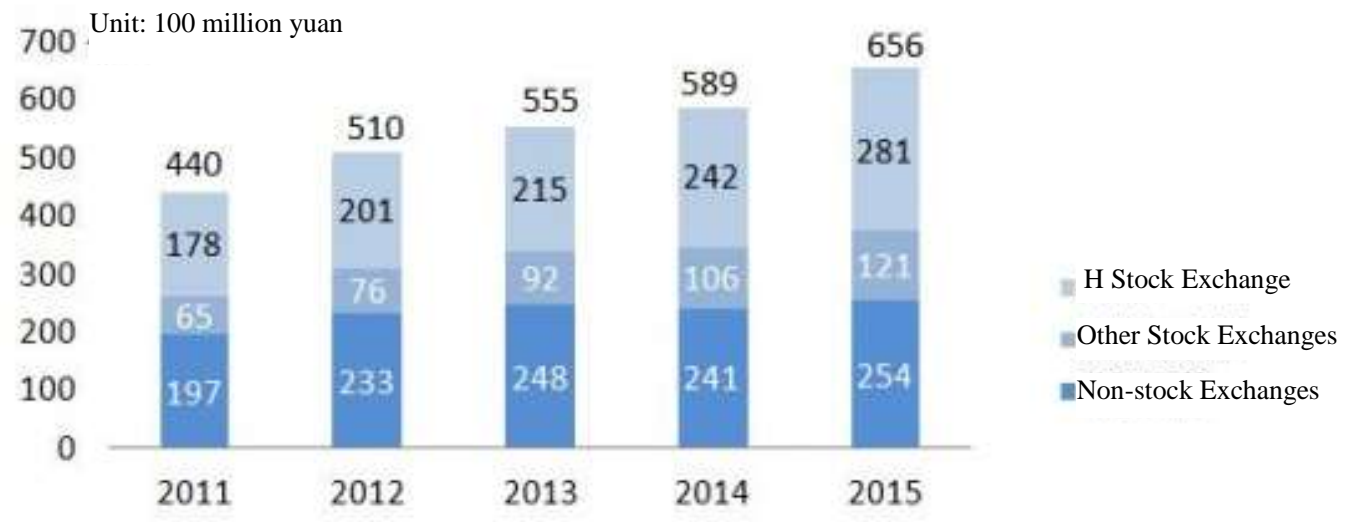

Fig. 1. 2011-2015 accounting service outsourcing market scale

In recent years, China's economy has developed at a rapid pace, and in the same period, accounting service outsourcing has also achieved leap-forward development. For a company, much attention has been paid to the assignment of non-core business such as information analysis and accounting processing to the corresponding agency, which has received good reputation from many companies. For the content of accounting outsourcing services, in order to meet the diversified needs of enterprises, the service content is also diversified, including the initial single accounting to the financial consulting, taxation distribution and other services, and for the service form, the outsourcing industry can establish a diversified cooperation with the enterprises, so that the two parties can achieve a win-win situation through the cooperation, additionally, regarding to the development of the outsourcing industry, big data lays a foundation for its inevitably better development and its wider business and its more talents.

With the gradual informationization and globalization of China's economy, accounting service outsourcing has begun to involve more industries. China has also recognized the importance to develop this business and is also trying to build its development power in this business. According to the companies recorded in the "2018 List of Chinese Listed Companies", there are 1,600 listed companies of China, 174,000 state-owned enterprises, 82,000 collective enterprises, 410,000 foreign-funded enterprises, and more than 2.2 million private enterprises. Therefore, in both accounting consulting and auditing development, China will become an indispensable service market in the world. With the increase of China's capital market and overseas activities, China's accounting industry has begun to have more connection with international accounting industry; although the number of accounting practitioners in China is huge, service outsourcing has a small share in the international market, and even the size of the market in China is not ideal. Its development mainly has the following features:

\section{A. The Basic Accounting Business Is Still the Core Business of Accounting Service Outsourcing}

At present, the scope of accounting services is relatively wide, including not only traditional tax planning, auditing, etc., but also accounting consulting, accounting system construction, etc. However, from the perspective of the development of this business in China, it cannot be realized as an accounting service for multinational enterprises. It also stays in the simple accounting business such as notes to accounting statement, bookkeeping agency, tax payment agency, etc, and cannot provide enterprises with higher level accounting business type service.

\section{B. Service Credibility Needs to Be Improved}

At present, there is no corresponding service credibility in China's accounting service organizations, so there are not many enterprises that apply for accounting service outsourcing actively. At the same time, this type of service organizations in China cannot compare with the international advanced institutions in terms of manpower, capital and scale, and there is an obvious gap between them. It is imperative to establish a higher service credibility to attract cooperative enterprises and carry out accounting service outsourcing business,

\section{Accounting Outsourcing Services Are Still Limited to the Low-end Market}

China's small and medium-sized enterprises are characterized by large quantity, small funds, small scale and insufficient personnel, it is difficult for them to guarantee the quality of accounting information. Therefore, they will buy accounting outsourcing service in order to reduce the expenses of enterprise welfare, salary and personnel training, and to 
better improve the integrity and accuracy of accounting information. As a result, the target customers of accounting outsourcing service in China are still small and medium-sized enterprises. This determines that accounting firms have less experience in accounting services for large enterprises. When middle and small-sized enterprises are listed or merged with development needs, domestic accounting firms cannot provide services for them, so China's accounting outsourcing services will only continuously seek development opportunities from the low-end market.

\section{The Level of International Business Processing Is Not High}

According to statistics, the current number of accounting practitioners in China has reached 19,000,000. As of September 30, 2017, the total number of individual members of the CICPA is 235,398, including 130,485 non-practicing members (586 non-practicing members from overseas, Hong Kong, Macao and Taiwan), and 104,913 practicing members (certified public accountant). There are 8,527 accounting firms across the country, including 7,461 head offices and 1,066 in branches.

From these data, it can be concluded that the reserve of accounting practitioners in China is sufficient, but their cognition in foreign language and international accounting practices is not ideal. Therefore, compared with Englishspeaking countries such as India, China is in a weak position in the field of accounting service outsourcing.

\section{E. Accounting Standards for Business Enterprises and International Financial Reporting Standards in China Have Also Achieved Convergence}

In order to achieve global economic integration, Accounting Standards for Business Enterprises and International Financial Reporting Standards in China were basically docked in 2006, and the internationalization of accounting service outsourcing laid the language foundation. In addition, the rapid development of information technology has built a more advanced technology platform. For example, the construction of software such as ERP system promoted by UFIDA and HP has made the intermediate management equipment more abundant, and better realized the international integration, decision-making development and knowledge sharing of the business. In this way, financial accounting, financial planning, financial management and other accounting work can spanned through IT tools. With the continuous transfer of global service industry to developing countries, China's accounting services outsourcing has a broader development market.

\section{F. A Good Policy Environment Promotes the Development of Service Outsourcing Business}

In 2007, relevant documents of the State Council clearly defined the international development of service, service outsourcing, and significance and role of opening. In the policy, international service outsourcing was positioned as a key point in the development of service trade, and pointed out its role in undertaking information management, technology research and development, and financial accounting. This policy has indicated that international accounting service outsourcing will become the development trend of the domestic accounting industry in the future. At present, Shanghai, Beijing and other more developed cities gradually established corresponding industrial bases while responding to policies. Local governments begin to transfer the business and regard internationalized accounting service outsourcing as the focus of industrial development. From the perspective of policies, it is conducive to the development of international accounting outsourcing service.

TABLE I. TABLE FOR COMMONALITIES OF ACCOUNTING SERVICE OUTSOURCING

\begin{tabular}{|c|c|c|c|}
\hline \multicolumn{4}{|c|}{ Commonalities of Accounting Service Outsourcing } \\
\hline \multirow{7}{*}{$\begin{array}{l}\text { Theoretical } \\
\text { basis of } \\
\text { outsourcing }\end{array}$} & $\begin{array}{l}\text { Theory of labor } \\
\text { division }\end{array}$ & \multirow[t]{7}{*}{$\begin{array}{l}\text { Risk of } \\
\text { outsourcing }\end{array}$} & $\begin{array}{l}\text { Risk of decision } \\
\text { making }\end{array}$ \\
\hline & $\begin{array}{l}\text { Theory of } \\
\text { comparative } \\
\text { advantage }\end{array}$ & & Stakeholder trust risk \\
\hline & $\begin{array}{l}\text { Theory of } \\
\text { principal-agent }\end{array}$ & & $\begin{array}{l}\text { Risk of service } \\
\text { quality }\end{array}$ \\
\hline & $\begin{array}{l}\text { Theory of } \\
\text { transaction costs }\end{array}$ & & $\begin{array}{l}\text { Risk of information } \\
\text { asymmetry }\end{array}$ \\
\hline & $\begin{array}{l}\begin{array}{l}\text { Theory of risk } \\
\text { management }\end{array} \\
\end{array}$ & & $\begin{array}{l}\text { Risk of external } \\
\text { environment }\end{array}$ \\
\hline & & & $\begin{array}{l}\text { Risk of transaction } \\
\text { cost reduction }\end{array}$ \\
\hline & & & $\begin{array}{ll}\text { Risk } & \text { of } \\
\text { confidentiality }\end{array}$ \\
\hline \multirow{5}{*}{$\begin{array}{l}\text { Motivations } \\
\text { of } \\
\text { outsourcing }\end{array}$} & Cost reduction & \multirow{5}{*}{$\begin{array}{l}\text { Decision- } \\
\text { making } \\
\text { factors of } \\
\text { outsourcing }\end{array}$} & Economic factor \\
\hline & $\begin{array}{l}\text { Enhancement of } \\
\text { core } \\
\text { competitiveness }\end{array}$ & & $\begin{array}{l}\text { External environment } \\
\text { factor }\end{array}$ \\
\hline & $\begin{array}{l}\text { Acquisition of } \\
\text { outsourcing } \\
\text { advantage } \\
\text { resources }\end{array}$ & & Strategic factor \\
\hline & $\begin{array}{l}\text { Improvement of } \\
\text { management } \\
\text { efficiency }\end{array}$ & & Management factor \\
\hline & $\begin{array}{l}\text { Focus of core } \\
\text { business }\end{array}$ & & Risk factor \\
\hline \multicolumn{4}{|c|}{ Characteristics of the Accounting Service Outsourcing } \\
\hline \multicolumn{4}{|c|}{$\begin{array}{l}\text { Accounting service outsourcing focuses on the outsourcing of accounting } \\
\text { related processes. } \\
\text { Choice of outsourcing service provider: } \\
\text { A higher professional requirements for outsourced service providers } \\
\text { The contract period for outsourcing is longer, and the accounting service } \\
\text { outsourcing contract requires long-term cooperation, usually seven to ten } \\
\text { years. } \\
\text { The confidentiality requirements of the outsourcing contract; the financial } \\
\text { data is the property of enterprises; more strict with confidentiality }\end{array}$} \\
\hline
\end{tabular}

\section{PROBLEMS OF ACCOUNTING SERVICE OUTSOURCING IN THE ERA OF BIG DATA}

In the era of big data, the problems in traditional businesses undertaken by the accounting service outsourcing industry have fully appeared, which has brought many new problems. From the perspective of its development status, the quality of information processing of accounting service outsourcing needs to be strengthened, and the functions of accounting service outsourcing need to be changed, the knowledge system of accounting service outsourcing talents needs to be improved, 
and the international accounting service outsourcing market needs to be expanded.

\section{A. The Quality of Information Processing of Accounting Service Outsourcing Needs to Be Strengthened}

The market situation changes rapidly in the informationbased society, and enterprises' development strategy should closely keep up with the changes of market. To this end, requirements on the authenticity, integrity and timeliness of accounting information will be higher. The traditional accounting service outsourcing mainly adopts the postprocessing method for information. That is to say, at the end of the year or in the middle term, the financial data of enterprises will be uniformly recorded to generate systematic financial information, and then it will be used by enterprises for further analysis, decision-making and forecast. However, market change may be real-time and random, and may not give enterprises enough time to prepare, which requires enterprises to respond to changes in a timely manner. Therefore, the lag time of financial processing is in conflict with the immediacy of market changes, which is not conducive to the management decisions of enterprises. Business is war without bullets, and mastering the right time is crucial to the survival and development of enterprises. If the information processing of accounting service outsourcing lags behind, the changes in the market and the needs of enterprise management will not be satisfied. For this reason, the quality of information processing of accounting service outsourcing needs to be strengthened.

\section{B. The Functions of Accounting Service Outsourcing Need to Be Changed}

The financial information and management information which can be referred and invoked gradually increase and improve in the era of big data. It is a great waste of resources if not fully, rationally and effectively using them. In addition, if the functions of accounting service outsourcing still remain in traditional accounting confirmation, measurement, recording, and reporting, it is obviously unable to meet enterprises' needs and long-term development. Big data and cloud computing technology are widely used, and accounting informationization develops rapidly, which provides sufficient data for enterprise management. These data cover all aspects of information such as market, same industry, product, production and so on, and they are the most powerful resources for enterprise management. Once the data useful for decision-making is not fully used by accounting service, the data resources generated will be greatly wasted. At present, accounting service outsourcing has not completely changed its functions, and most accounting service outsourcing is still providing original financial accounting and basic financial statistics services. In the era of big data, the functions of accounting service outsourcing urgently need to be changed.

\section{The Knowledge System of Accounting Service Outsourcing Talents Needs to Be Improved}

With the development of big data, the industry has also begun to step into more fields such as human resources consulting, social security investigation, bookkeeping agency, etc, so it will put forward deeper requirements for accounting talents. At present, China does not attach importance to it, which will inevitably cause that accounting talents cannot satisfy the needs of customers for specialization. In addition, students trained by colleges and universities have a serious problem of disconnection between theory and practice, so talents output by colleges and universities are difficult to become the accounting service talents required by enterprises in a short period of time. The above two points have led to the low quality of accounting service talents at present, affecting the accounting service outsourcing.

\section{International Outsourcing Market Still Needs to Be Developed}

The international labor cost difference is based on multinational service outsourcing. At present, many accounting service outsourcing background providers come from Asia, it is mainly because practitioners in this industry are both suitable in education level and service price in Asia. $30 \%$ of the cost can be saved if transferring the service background from the US to India. Through the above analysis, as a developing country, China's accounting service outsourcing industry will inevitably be inclined to the direction of developed countries.

From the perspective of international practice, at present, services that the firm can provide include: employee compensation and welfare treatment, insurance calculation, insurance payment, land tax declaration, agency accounts, employee bonus treatment, cashier business agent, etc. In short, all financial works of enterprises can be completed by accounting firms assigned by accounting service outsourcing. In general, in addition to their professional capabilities, suppliers who provide accounting service outsourcing also should be recognized by customers with the following factors: (1) quality service commitment of outsourcers; (2) reasonable service price of outsourcers; (3) good service reputation of outsourcers; (4) flexible service contract clause of outsourcers; (5) rich service resource scope of outsourcers; (6) value-added service of outsourcers; (7) adaptive service culture of outsourcers; (8) location of outsourcers.

From the above analysis, it is easy to conclude that if the domestic accounting service institutions want to achieve international development, they should not only obtain the recognition of contract issuing unit in terms of business capability, but also improve their competitive strength in many ways. That is to say, only by doing this, outsourcers are likely to become the dominant outsourcers of the industry. Therefore, we still need to explore the international outsourcing market and strive for the corresponding international outsourcing market.

\section{MEASURES FOR FURTHER DEVELOPMENT OF ACCOUNTING SERVICE OUTSOURCING INDUSTRY IN THE ERA OF BIG DATA}

\section{A. Transforming from Final Accounting to Real Time Accounting}

We can transfer from the final accounting to real time accounting in order to strengthen the quality of information 
processing of accounting service outsourcing and better meet the requirements of authenticity, integrity and timeliness of accounting information. The traditional accounting service outsourcing usually obtains and processes enterprises' financial information at the end of the period, which causes the lag of the enterprise information and affects the financial decision. The development of Internet technology and the advent of the era of big data have provided sufficient technical support for the application of real time accounting. Enterprises can network with accounting service outsourcing enterprises to upload their own business activities in a timely manner. The outsourcing enterprise immediately processes the information and uses big data technology to process and analyze it. On the one hand, it will be recorded; on the other hand, the analysis results will be immediately fed back to the enterprise, so that the enterprise can make a rapid strategic management response accordingly.

\section{B. Transforming from Financial Accounting to Management Accounting}

In the era of big data, enterprises can not only satisfy the information brought by financial accounting, but also require special institutions to help enterprises make business decisions and provide financial forecasting information, so as to realize the functions of management accounting. If the accounting service outsourcing enterprises do not carry out transformation and adjustment and not keep up with the changes in the development of the times, it will be difficult for them to have a long-term foothold in a competitive market. The accounting service outsourcing enterprises can summarize, classify, refine and organize the market data and the industry information required by their customers, and deal with the financial information of enterprises in a timely manner. They compare these information separately, produce decision reports, and transmit them to information users. According to the actual situation, information users can continuously propose new requirements to accounting service outsourcing enterprises so as to meet the needs of production and operation. In addition to providing basic data, accounting service enterprises should also understand the industry trend and send updates to enterprises at any time. Enterprises and accounting service outsourcing enterprises should transmit information to each other from time to time, so as to meet the data demand, promote each other, form a virtuous circle management system, jointly promote the development of enterprises, complete the rational allocation of resources and improve market competitiveness.

\section{Developing Towards Perfect Organization and Mechanism Construction}

When accounting service outsourcing enterprises are enclosed by the time of big data, the construction of their organizations and mechanisms has a close relationship with their development. Accounting service outsourcing enterprises should lay a solid foundation through system construction, comprehensively consider the development status and development trend of this industry, and ensure that business development and personnel handling can be carried out in a perfect management rule and management system. In order to improve the organization and mechanism construction, the enterprises must incorporate various factors such as customer evaluation and employee performance when formulating reasonable and normative incentive mechanisms and regulations. This incentive method promotes communication between accouters and customers, deepen their mutual understanding, timely discover the deficiencies in the service, and better provide customers with personalized accounting service outsourcing; second, develop appropriate charging standards and the level and time may also be taken into consideration, and define the service quality of the corresponding charging standards. While meeting the needs of different enterprise's customers for different services, the cost will be reduced but the service quality will be not; third, force employees make confidentiality for the customer's accounting information based on system. The perfect accounting service outsourcing institutions and mechanism is the premise to achieve the overall improvement of management level and service quality. Therefore, we must do a good job in brand building and scale construction when ensuring the development of the industry.

\section{Transforming from Professional Talents to Compound Talents}

When the market environment and market economy become more complicated, the accounting service outsourcing taking big data as development foundation should regard market demand as development orientation, and combine talent training with technology to effectively solve the current phenomenon of low talent quality. Colleges and universities should reform the knowledge output system, ensure that the knowledge output system can be combined with the curriculum construction, and refine them according to the differences in majors and positions, and arrange the courses to effectively allocate resources. Reasonably set up courses, carry out multi-disciplinary construction, and cultivate compound talents to meet the needs that modern accounting service outsourcing develops towards multi-fields.

In terms of industry intensity, the industry is knowledgeintensive and has great demand for professionals. At present, in the face of the problem of large demand gaps for professionals, the state and enterprises should do a good job of propaganda, so as to attract more people to devote themselves to this industry. On the one hand, we will strengthen the attraction of people who are already employed; on the other hand, we will strengthen the attraction of high school graduates and enable more people to enter colleges and universities to learn related knowledge. In the era of big data, multi-faceted propaganda can reserve more professional talents in time, so as to achieve better and faster development of service outsourcing on the basis of sufficient number of talents. Moreover, we will strengthen the internationalization of accounting personnel training, set up courses in foreign languages, international regulations, and international business, guide students to develop towards international talents, and lay a good talent foundation for exploring the international market in the future. 


\section{E. Developing Towards Scale Expanding}

Big data will inevitably drive the development of the accounting service outsourcing industry, and can also promote the effective integration of the industry. Large accounting service industry institutions can acquire small service providers to achieve the expansion of the scale of corresponding industrial institutions. However, the construction of big data platform requires an opportunity, while such integration needs to be based on certain data commitment. We will achieve leading enterprise development in this field and strengthen the competitiveness of the accounting service outsourcing industry at home and abroad. On the basis of integration, we can use the cloud platform as the foundation, form a unified deployment through the services provided by platform services and IT applications, and carry on the superiority promotion to its development.

\section{F. Close to the Needs of the Cooperative Enterprise}

In the current era of big data, the demand of cooperative enterprises is a powerful driving force for industrial development. First, the qualification and business quality of the accounting service outsourcing industry are the key points in the investigation of cooperative enterprises. In addition, it also involves the service concept, service reputation, ranking and other items of service institutions. Second, the cooperative enterprises can put forward specific requirements for information connection and communication in the process of cooperation with the service institutions. Third, after the completion of the cooperation, effective improvement measures will be proposed based on the evaluation of the service quality of the cooperative enterprises. In this way, we can ensure timely discover problems and effectively resolve them during cooperation, so as to achieve the solution of the corresponding problems and make the industry develop well.

\section{G. Increasing the Internationalization of Accounting Service Outsourcing}

1) Standardizing and integrating consulting services, tax and accounting services as soon as possible: In the past, the government-dominated intermediary service market led to the closure and monopoly of the intermediary service market, and bound and hindered the further development of the service trade market. This kind of phenomenon needs to be solved urgently. Only in this way can we occupy a larger share in the market, occupy more markets, and continue to develop the market. To this end, the firm should do a good job of selfintegration on the basis of enhancing its own competitiveness, thus driving the development of the entire industry.

2) Paying attention to the cooperation with corresponding institutions in other countries: The premise of promoting the development of domestic service institutions is the cooperation between domestic service providers and large international institutions. First of all, large firms have a good qualification and faith, and the degree of internationalization of accounting services is also high. Many employees with international quality will also promote and influence the professional quality of domestic employees to get a better promotion, so as to realize the integration of accounting services with the international market as soon as possible, and guide accounting service institutions to quickly enter the international market. Hong Kong accounting firms will be the largest partner in China in the entire service market. First, such firms in Hong Kong have a large customer base, including mainland investment enterprises, multinational enterprises, and listed enterprises. Second, to develop domestic accounting service institutions and realize oversea expansion, the exchange between the mainland and Hong Kong will promote its continuous development in a mature way. Third, the entry of Hong Kong accounting service outsourcing is bound to promote the improvement of the competition system.

3) International accounting talents bring new industry standards, international vision and business norms to the domestic market: In accordance with international standards, the international market and mainland market have put forward higher requirements for the service level of accounting outsourcing service personnel. Therefore, professional accounting talents who are skilled in dealing with accounting business in accordance with internationally accepted accounting standards will be popular. Meanwhile, international accounting talents have brought new industry standards, international vision and business norms to the domestic market, which will enhance the comprehensive quality of accounting talents.

\section{CONCLUSION}

With the development of the Internet and information industry, big data has also penetrated into the accounting service outsourcing industry. Based on big data, accounting service outsourcing has realized effective cost saving and more professional development. The accounting service outsourcing with big data has received more attention, and needs of service receivers have become more diversified. Therefore, it is necessary to explore the existing problems and give solutions.

This paper first analyzes the development of accounting service outsourcing industry in the era of big data. For example, the basic accounting business is still the core business of accounting service outsourcing; the credibility of service needs to be improved; accounting outsourcing service is still limited to the low-end market; the level of international business processing is not high; the Accounting Standards for Business Enterprises and International Financial Reporting Standards in China have also achieved convergence; good policy environment has promoted the development of service outsourcing business. It further explores the following problems: the quality of information processing of accounting service outsourcing needs to be strengthened; the functions of accounting service outsourcing need to be changed; the knowledge system of accounting service outsourcing talents needs to be improved; international outsourcing market still needs to be developed. Finally, in view of the above problems, it proposes measures for the further development of the accounting service outsourcing industry in the era of big data: transforming from final accounting to real time accounting, 
transforming from financial accounting to management accounting, developing towards perfect organization and mechanism construction, transforming from professional talents to compound talents, developing towards scale expanding, close to the needs of the cooperative enterprise, increasing the internationalization of accounting service outsourcing.

\section{REFERENCES}

[1] Qin Zheng, Ji Cheng, Xu Xingfeng, Lan Tianshan, Yang Yang, Ding Xiaochao. Research on the Development Policy of Service Outsourcing Industry under the Background of Cloud Computing and Internet of Things [J]. Intertrade, 2011 (07): 62-68.

[2] Zou Chunyan. Research on the Development of Service Outsourcing Industry in Heilongjiang Province under the Influence of Cloud Computing [J]. Foreign Economic Relations \& Trade, 2014 (01): 94-96.

[3] Wang Xuan. Service Outsourcing Talents Training under the Background of Internet of Things and Cloud Computing- Taking Fujian Service Outsourcing College as an Example [J]. Journal of Changji University, 2016 (03): 125-130.

[4] Xie Xiaohua. Analysis of Cost and Benefits of Accounting Outsourcing Services in Private Enterprises[J]. Finance and Accounting Monthly, 2005 (22): 21-22.

[5] Zhuo Yue. An Analysis of the Finance and Accounting Outsourcing Market [J]. The Chinese Certified Public Accountant, 2005 (01): 30-32.

[6] Wang Jinli. Outsourcing in Listed Companies: the Chance and Challenge of the CPA [J]. Communication of Finance and Accounting (Academy Version), 2007 (05): 54-56.

[7] Wu Yanqin. An Analysis of Outsourcing Risk Factors and Implications on Accounting Practice [J]. Journal of Wuhan University of Technology (Information \& Management Engineering), 2007 (04): 149-152.

[8] Chen Xiaoying. On the Internationalization of Accounting Talents Training in Colleges and Universities from the Development of International Accounting Outsourcing Business [J]. Intemet Fortune, 2008 (04): 31-32.

[9] Meng Cuihu, Song Xiaochuan. Realization Way of Accounting Outsourcing in the United States and India and the Development Trend of Accounting Outsourcing in China [J]. Modern Business, 2009 (14): 212-213.

[10] Chris Fill, Elke Visser. The outsourcing dilemma: a composite approach to the make or buy decision[J]. Management Decision,2000,38(1). 